\title{
Observations on the calving of free-ranging tame red deer (Cervus elaphus)
}

\author{
Pamela Arman*, W. J. Hamilton $\dagger$ and G. A. M. Sharman $\ddagger$ \\ Institute of Terrestrial Ecology, Hill of Brathens, Banchory, Kincardineshire AB3 4BY; \\ $\dagger$ Hill Farming Research Organisation, Glensaugh Farm, Kincardineshire; and \\ $\ddagger$ The Rowett Research Institute, Bucksburn, Aberdeen AB2 9SB, U.K.
}

\begin{abstract}
Summary. Calving was observed in 27 farmed red deer, most of which were calving for the first time. On average, parturition lasted $107 \mathrm{~min}$ and the placenta was released 98 min after calving. The postnatal development of 23 calves was watched. On average, the first sucking occurred $33 \mathrm{~min}$ after birth and the calves were able to stand $47 \mathrm{~min}$ after birth. There was wide variation in these times. Male first calves had a mean weight of $6.59 \mathrm{~kg}$ and females a mean weight of $6.00 \mathrm{~kg}$, weighed dry after the first sucking. Out of 50 hinds put to the stag at 16 months of age, when their mean weight was $66 \mathrm{~kg}$, 48 calved. None of 56 pregnant hinds, of which 50 were in their first pregnancies, died at calving time. Calf losses were 3 born dead and a further 6 which died soon after calving: these losses were $16 \cdot 1 \%$ of pregnancies and $11.3 \%$ of calves born alive.
\end{abstract}

\section{Introduction}

Studies of the population dynamics of Scottish red deer have shown that on poor hill land most of the adult and calf mortality occurs in late winter and early spring, when their nutritional status is low and weather is often severe (Lowe, 1969; Mitchell, McCowan \& Parish, 1971). In areas where the deer are better nourished and winter mortality is low, e.g. in Glen Dye, Kincardineshire, and in farmed deer, perinatal calf losses may, on the other hand, be the most important factor affecting recruitment into the population (Staines, 1978). Of 6 captive red deer kept and studied indoors, 2 had difficulty in calving and 2 showed initially poor lactation (Arman, 1974) but the importance of perinatal calf mortality in June and July in wild deer is difficult to assess, because dead calves are not often found.

Since 1970, the Rowett Research Institute and the Hill Farming Research Organisation have been investigating the farming of red deer on the eastern foothills of the Grampian Mountains in Kincardineshire (Blaxter, Kay, Sharman, Cunningham \& Hamilton, 1974) and the present report arose from the opportunity to watch calving in 56 tame hinds ranging freely in large paddocks.

\section{Materials and Methods}

The deer farm

The farm consisted of some $2200 \mathrm{~km}^{2}$ of rough hill land divided naturally into an upper undulating peaty moorland at $350-450 \mathrm{~m}$ elevation where the hinds spent most of the winter, and two conjoined valleys on the steeply sloping sides of which the calvings were observed. The whole area was enclosed by high tensile fencing and subdivided. The 4 paddocks in which the calving hinds were watched ranged from $170-310 \mathrm{~m}$ and from $2.4-8.8 \times 10^{4} \mathrm{~m}^{2}$. Over most of the area the vegetation was dominated by heather (Calluna vulgaris) with associated blaeberry (Vaccinium myrtillus), bracken (Pteridium aquilinum) and herbs: there were some wet patches dominated by grasses, sedges and rushes.

* Present address: Airy Park Cottage, Contlaw Road, Milltimber, Aberdeen AB1 0ER, U.K. 
An observation hut at about $280 \mathrm{~m}$ altitude commanded views over most of 3 of the enclosures, and a tent was put up to permit observation of part of the ground invisible from the hut.

\section{Animals and management}

In 1971, 49 female calves were captured from the wild when $<1$ week old and hand-reared, becoming very tame (Nos 1-49). They were released at the farm in September when 3 months old. From then until the following April they were led daily into a small enclosure where they were fed ewe and lamb pellets in troughs at the rate of $0.9 \mathrm{~kg} / \mathrm{calf}$ per day and then returned to the moorland grazings. To this group was added one hind born and suckled in captivity. All these hinds were mated as yearlings between October and December 1972 when they weighed 56-76 kg (mean $66 \mathrm{~kg}$ ). One died in the winter as the result of an accident. Of the 49 left, 48 produced calves. One had a manually assisted stillbirth in May and the other 47 were used at 2 years of age for the calving study in June-July 1973.

In addition, observations were made on 6 calves (Nos 52-61) caught in 1970 and hand-reared, which calved in 1973 as 3-year-olds ( 2 for the first time), a 5-year-old carrying her second calf and an older hind which had calved several times in the wild.

The hinds were given a barley-based concentrate during May and June at the rate of $0.5 \mathrm{~kg} / \mathrm{hind}$ per day and were led into the handling area for weighing and udder examination twice weekly. At the end of May, those which were thought, from their weight gain and udder development, to be going to calve first were separated and put into the observation paddocks.

\section{Techniques of observation}

Each hind was fitted with a numbered, colour-coded cattle calf collar (Dalton \& Co., Henley-onThames, Oxon.). A 24 -h rota watch was maintained from 4 June to 3 July 1973 . The observers used tripod-mounted Zeiss binoculars of magnification 12-40 $\times 80$ and also smaller binoculars for scanning, telescopes for use away from the hut and 2-way radios for liaison with the office and other workers on the farm. Night observations were made with a Night Viewing Device SS32 (Rank Precision Instruments). During mist, and for about $3 \mathrm{~h}$ each night, details could not be seen and a few deer calved out of sight of the observers. The 10 observers, all but one of whom had had considerable previous experience of observing red deer, were given instructions and record sheets on which to enter calving details. All observations were made from distances of 50-500 m (most from $300 \mathrm{~m}$ ) and nearly all the hinds were unaware of being watched. A few closer approaches were made to places not visible from the hut.

Some time after the birth, and usually after the calf was dry and suckled, it was weighed and sexed. A correction of $0.1 \mathrm{~kg}$ was added to the weights of the 4 calves which were weighed wet and unsuckled.

\section{Behaviour of the hinds}

\section{Results}

The hinds had a marked diurnal behaviour pattern, which varied according to the weather. They usually moved downhill to the bottom corner of their enclosure by 08:00-08:30 $\mathrm{h}$ and waited for the food which was brought at 09:00-10:00 h. After feeding they tended to rest along the lower side of their enclosure, moving upwards in the late morning or early afternoon, and to spend the night at higher altitude.

In late pregnancy the hinds spent much time resting, but most became restless a few days before calving and often paced along the fences. A few became aggressive, or bellowed. With few exceptions, their udders filled out and vulvas became swollen shortly before parturition. The first weak contractions probably caused little change in behaviour and were not seen by the observers. When contractions became stronger the hind stopped grazing and settled in one area, alternately standing and lying, often with legs extended. Very strong contractions caused the hind to roll and obvious signs of straining were seen. The observers usually knew which hinds to watch closely, but the times when the contractions were first seen could have been some time after they were first initiated. The hinds were sometimes alone and sometimes near others when they calved. 


\section{Events during parturition}

Full observations were obtained for 15 calvings and some data from a further 12: the results are shown in Table 1. In 19 out of 24 calvings seen, the hind was lying down when the calf was expelled. The fluids and placenta were licked up and eaten. The calves were normally accepted and cleaned immediately, but in 6 instances the hind first rested for 2-5 min. Only one calf was rejected by its mother after a normal birth, when she was disturbed when the morning feed was brought into the enclosure. Her calf was bottle fed but died later. One hind adopted a second calf in addition to her own 5 days after calving. In 22 out of 25 births, presentation was normal (front feet first, followed by head) and parturition was trouble-free. One easy birth occurred with the hind legs presented first. The data on 3 abnormal calvings (Nos 11, 37 and 38, all calving for the first time at 2 years of age), of which details are given below, have been excluded from Table 1.

Table 1. Observations on normal calvings in farmed red deer

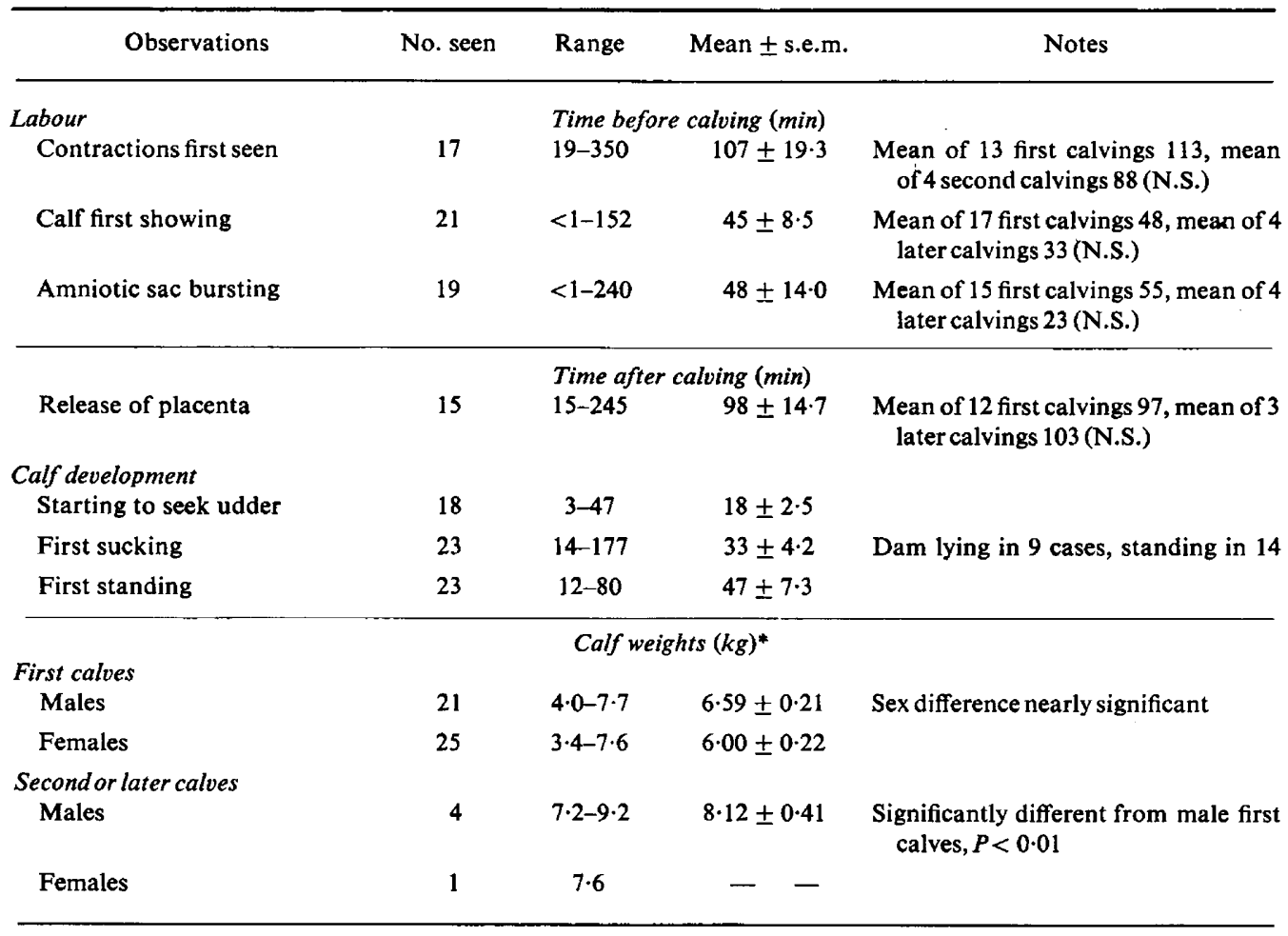

* Weighed dry and after first sucking. $0.1 \mathrm{~kg}$ added to 2 male and 2 female calves weighed wet and empty.

\section{Time and site of calving}

Of the 34 hinds which calved during the study period, 20 did so from 09:00 to 17:00 h, between 7 and 9 hinds calved in the period 17:00-01:00 h and between 5 and 7 hinds calved in the period $01: 00-09: 00 \mathrm{~h}$. There was thus a bias towards calving in the daytime. Over half the hinds calved at low altitude.

\section{Calving and lactation problems and hind and calf mortality}

Hind 23 staggered into a stream during parturition and the calf was dropped into shallow water. The hind stepped out and continued cleaning up the fluids on the grass, ignoring the calf, which would have become chilled and drowned but for rescue by the observer, who put the calf on the bank. The hind stood a few yards away and accepted the calf 10 min later. Similar behaviour by 2 other hinds 
when separated from the calf on a steep slope suggests that the hinds are primarily attracted by the smell of the fluids, and that licking of the calf is at first incidental.

The feet of Hind 11's calf showed 111 min after contractions were first seen. Contractions continued, with the feet alternately extruded and retracted, for a further $4 \mathrm{~h}$. Eventually they almost ceased and the hind resumed grazing. Calving was assisted after manual correction of an abnormal presentation, which was lateral deviation of head and neck. Both hind and calf were very weak and the calf was not accepted until $1 \mathrm{~h}$ after delivery.

After contractions had lasted for $9 \mathrm{~h}$, calving of Hind 37 was assisted : the presentation was normal but the cervix was very tight. The calf was rejected and died after 1 day.

Hind 38 had weak contractions at intervals for 2 days and was very restless. She was moved to the handling pens but then calved without help. She had little milk and her calf was weak and died after 3 days.

Hind 51 developed a vaginal infection the day after calving and her calf died 2 days later, apparently from shortage of milk. The calf of Hind 3 also died from shortage of milk and that of Hind 20 died after becoming separated from its mother by a fence. Hind 30 gave birth to a dead calf and Hind 9 had a dead, full-term calf removed. These problems all occurred with hinds having their first calf. It is difficult to assess what would have happened at some of the calvings without veterinary or other intervention. Calf losses were $16.1 \%$ of pregnancies and $11.3 \%$ of those born alive and would probably have been of similar magnitude without human interference. Veterinary treatment did, however, prevent loss of at least one hind.

\section{Discussion}

The details of parturition recorded in Table 1 are similar to those described for captive red deer by Arman (1974), for sheep by Hersher, Richmond \& Moore (1963) and for hartebeest (Alcelaphus buselaphus) by Gosling (1969). Parturition and calf development are more rapid in the wildebeest (Connochaetes taurinus), in which predation on newborn calves is high (Estes, 1966). Maternal and early calf behaviour have been described by Arman, Kay, Goodall \& Sharman (1974), CluttonBrock \& Guinness (1975) and Kelly \& Drew (1976).

The pattern of diurnal movement in our hinds, with most animals on low ground in the morning, is the opposite of that of wild deer in summer, which tend to spend the nights on low ground and move upwards in the daytime (Darling, 1937; Lowe, 1966). It is likely that wild deer climb by day to escape disturbance, whereas our tame deer came down in the morning for the supplementary food. Since most calvings occurred during the daytime, from 09:00 to 17:00 $\mathrm{h}$, a high proportion of the births were also on low ground. Calving hinds were not always alone. Those which were alone may not have deliberately moved away: normal movements of the other hinds, while a hind in labour remained in one place, could account for their separation. Fences may, however, have prevented withdrawal in some cases.

Red deer conceive at 16 months of age only when they are well grown. In poor areas of Scotland, puberty is not attained until hinds are $2-3$ years old or more. Where deer density is lower and nutrition a little better, up to $25 \%$ of yearlings may conceive: those doing so have a mean autumn weight of $66 \mathrm{~kg}$ compared with $54 \mathrm{~kg}$ in infertile yearlings (Mitchell, 1973). A yearling pregnancy rate of $67 \%$ was recorded in Glen Dye, an area of low deer density close to the deer farm, by Staines (1978). In very favourable areas, e.g. lowland deer parks (Mitchell, 1973) or rich habitats in New Zealand (Daniel, 1963), yearling pregnancy rates of $80-90 \%$ have been recorded, and in farmed deer in New Zealand a $91 \%$ calf crop was obtained from 2-year-old hinds (Drew, 1976). The results of the present study are in agreement with the above findings: of our yearling hinds, which had a mean autumn weight of $66 \mathrm{~kg}, 98 \%$ were pregnant in 1973, indicating good nutrition and successful management.

Birth rates in wild red deer populations vary from 70 calves per 100 hinds over 1 year old down to 40 per 100 or even less. The main influences are the age at puberty and the conception rate of adult hinds. Mature wild hinds, especially those which are lactating, show reduced fertility when undernourished (Mitchell, 1973). Calf mortality is also an important factor in recruitment. Sustainable 
culls vary from one-sixth to one-third of wild populations (Mitchell, Staines \& Welch, 1977). In farmed deer, with low stag : hind ratios, culls could be higher.

None of our hinds was lost at calving time, although one might have died without veterinary treatment. Deaths of wild hinds at calving time are also very infrequent. Overwinter mortality in wild Scottish stocks averages 3-5\% of adults and 10-12\% of calves (Mitchell et al., 1971). The main unknown factor in the population dynamics of wild stocks is the extent of calf mortality in the calving season. Staines (1978) estimated that $29-44 \%$ of calves, mainly from first-calvers, disappeared between pregnancy and autumn in Glen Dye. On a farm in New Zealand, in the first year when the hinds had been brought in only 6 weeks before parturition, calf mortality was $21 \%$, largely due to bullying by the hinds, but in later years losses were only $5 \%$ (Drew, 1976). In our study, losses were $16.1 \%$ of pregnancies $(11.3 \%$ of live births) from a group of 56 hinds of which 50 were pregnant for the first time. These results provide further evidence that perinatal calf mortality may be quite high in first-calvers and may have a significant effect on recruitment into deer populations. Even in a farming situation, the losses could not have been prevented.

We should like to record our appreciation to the Hill Farming Research Organisation for the use of the facilities at Glensaugh and for the patience and careful observation of the following, who joined with P.A. and G.A.M.S. in manning the rota: J. Crisp, R. Hesketh, B. Mitchell, T. Parish. K. Sharman, A. Simpson, B. W. Staines and J. Stevenson.

\section{References}

ARMAN, P. (1974) A note on parturition and maternal behaviour in captive red deer (Cervus elaphus L.). J. Reprod. Fert.37, 87-90.

Arman, P., Kay, R.N.B., Goodall, E.D. \& Sharman, G.A.M. (1974) The composition and yield of milk from captive red deer (Cervus elaphus L.). J. Reprod. Fert. 37, 67-84.

Blaxter, K.L., Kay, R.N.B., Sharman, G.A.M., Cunningham, J.M.M. \& Hamilton, W.J. (1974) Farming the Red Deer. Dept. of Agriculture \& Fisheries for Scotland. H.M.S.O., Edinburgh.

Clutton-Brock, T.H. \& Guinness, F.E. (1975) Behaviour of red deer (Cervus elaphus L.) at calving time. Behaviour 55, 287-300.

DANiel, M.J. (1963) Early fertility of red deer hinds in New Zealand. Nature, Lond. 200, 380.

Darling, F.F. (1937) A Herd of Red Deer. Oxford University Press, London.

Drew, K.R. (1976) The farming of red deer in New Zealand. Wld Rev. Anim. Prod. 12, 49-60.

Estes, R.D. (1966) Behaviour and life history of the wildebeest (Connochaetes taurinus Burchell). Nature, Lond. 212, 999-1000.

Gosling, L.M. (1969) Parturition and related behaviour in Coke's hartebeest, Alcelaphus buselaphus cokei Günther. J. Reprod. Fert., Suppl. 6, 265-285.

Hersher, L., Richmond, J.B. \& Moore, A.U. (1963) Maternal behaviour in sheep and goats. In Maternal
Behaviour in Mammals, pp. 203-232. Ed. H. D. Rheingold. Wiley, New York.

KELLY, R.W. \& DREW, K.R. (1976) Shelter-seeking and sucking behaviour of the red deer calf (Cervus elaphus) in a farmed situation. Appl. anim. Ethol. 2, 101-111.

LOWE, V.P.W. (1966) Observations on the dispersal of red deer on Rhum. Symp. zool. Soc. Lond. 18, 211-228.

LowE, V.P.W. (1969) Population dynamics of red deer (Cervus elaphus L.) on Rhum. J. anim. Ecol. 38, 425-457.

MitChell, B. (1973) The reproductive performance of wild Scottish red deer, Cervus elaphus. J. Reprod. Fert., Suppl. 19, 271-285.

Mitchell, B., McCowan, D. \& Parish, T. (1971) Some characteristics of natural mortality among wild Scottish red deer (Cervus elaphus L.). Proc. 10th Int. Union Game Biol., pp. 437-450. Liber Tryck, Stockholm.

Mitchell, B., Staines, B.W. \& Welch, D. (1977) Ecology of Red Deer. Institute of Terrestrial Ecology, Cambridge.

STAINES, B.W. (1978) The dynamics and performance of a declining population of red deer (Cervus elaphus). J. Zool., Lond. 184, 403-419.

Received 30 January 1978 